IRSH 65 (2020), pp. 289-3 I 4 doi:I0.1017/So020859019000555

(C) 2019 Internationaal Instituut voor Sociale Geschiedenis

\title{
Women in the Silver Mines of Potosí: Rethinking the History of "Informality" and "Precarity" (Sixteenth to Eighteenth Centuries)
}

\author{
Rossana BarRagán Romano \\ International Institute of Social History \\ Cruquiusweg 3I, IOI9 AT, Amsterdam, the Netherlands \\ E-mail: rba@iisg.nl
}

\begin{abstract}
AвSTRACT: Underground mining in Potosí was a male sphere. Nevertheless, women were actively involved in the early stages of silver mining in Potosí, when traditional technologies were still in use. They also played an important role in the local ore market. After the introduction of new technology and the reorganization of the labour force, the process of refining ore was much more complicated. Women then participated in some stages of the process: in selecting the ores and sieving. This implies that mining is a complex process with a labour and gender division that has been underrated and underestimated. More importantly, women became owners of rudimentary mills (trapiches) where the ore was processed, selling different amounts of silver to the Spanish authorities, making their living in this way.
\end{abstract}

\section{INTRODUCTION}

Ten years ago, Laurie Mercier and Jaclyn Gier wrote, in a pioneering book, that there were no studies at that time that "discuss the multidimensional aspects of women's work as miners and as miner's wives and the impact of gender differentiation in mining in a global/historical context". ${ }^{\mathrm{I}}$ At present, we certainly have more studies, particularly on women's presence in mining in recent decades, although historical studies remain scarce, due, in part, to under-recording and also to the scarcity of sources available in the archives as a result of the underestimation of women's work and employment.

Potosí (Figure I), which produced sixty per cent of the silver of Latin America in the second half of the sixteenth century and became one of the

\footnotetext{
* I am grateful to the anonymous reviewers and to the Editorial Committee for their valuable comments.

I. Laurie Mercier and Jaclyn Gier (eds), Mining Women: Gender in the Development of a Global Industry, ${ }_{1670-2005}$ (New York, 2006), pp. 3 and 32.
} 


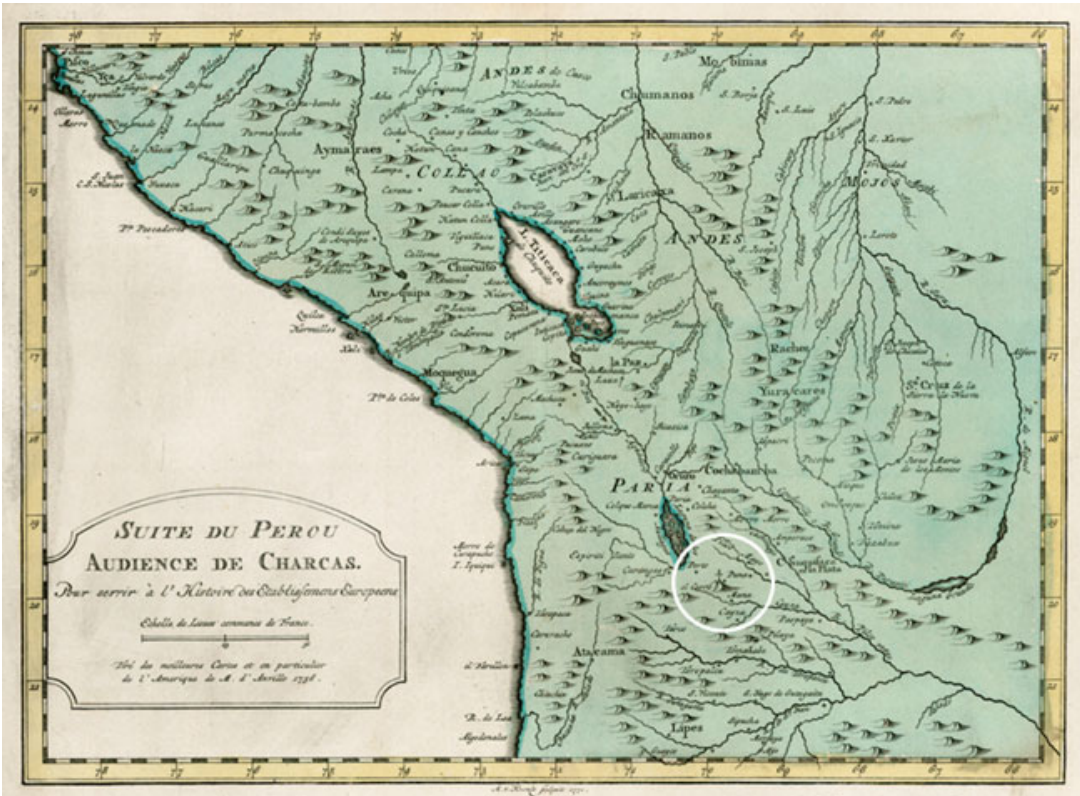

Figure I. The location of Potosí on an eighteenth-century map.

most populous cities at that time, has also been identified with male labour. ${ }^{2}$ Its production in its "silver age" was related, in large part, to the mita, the labour system of pre-Hispanic origin, established by Viceroy Francisco de Toledo in the I570s, consisting of an annual draft labour system of I 2,000 to 14,000 Indian workers between eighteen and fifty years of age, recruited across sixteen provinces. ${ }^{3}$ Potosí's historiography focused mainly on this

2. Arturo Giráldez, "Born with a Silver-Spoon: China, American Silver and Global Markets during the Early Modern Period", (Ph.D., Universiteit van Amsterdam, I999), p. 40; Dennis Flynn and Arturo Giraldez, "Born with a 'Silver Spoon': The Origin of World Trade in I57I", Journal of World History, 6:2 (1995), pp. 20I-22 I, p. 209. It is frequently quoted that the city reached 160,000 inhabitants at the beginning of the seventeenth century. Although this number is not very reliable, it had 145,000 in 1660 and I 10,000 in 1680. Tandeter, quoted by Jane E. Mangan, Trading Roles: Gender, Ethnicity, and the Urban Economy in Colonial Potosi (Durham, NC, 2005), p. 165. The population of London in the mid-1670s was approximately 500,000 and Paris had around 400,000 inhabitants by 1640 .

3. The mita system, of Inca origin, existed in Potosí after the discovery of silver although not on the vast scale acquired since its establishment in late 1572 . Paula Zagalsky gives a detailed account of the number of mitayos. Paula Zagarsky, "La mita de Potosí: una imposición colonial invariable en un contexto de múltiples trasformaciones (siglos XVI-XVII. Charcas, Virreinato del Perú), Chungará. Revista de Antropologia Chilena, 46:3 (2014), pp. 375-395. The classic studies on Potosí and Indian labour remain Alberto Crespo Rodas, "La 'mita' de Potosí", Revista Histórica, 22 (1955-1956), pp. 169-182; Peter Bakewell, Miners of the Red Mountain: Indian 
male labour of the mita. However, these men travelled with their wives and family, making a total of around 40,000 people who migrated temporarily to Potosí each year. We therefore still have just part of the history, because we have scarce information about those family members who accompanied the workers. Few scholars have written about the women involved in this temporary migration to the mines and on their role in the city. Brooke Larson was a pioneer in analysing the tasks performed by indigenous women in the formation of this early colonial mercantile economy. Later, Bianca Premo dedicated a thoughtful piece to the "gendering of mita" and to women who stayed in their provinces facing the mita effects on their rural lives. In 2004 and 2005, two important books on women in Potosí were published. Jane Mangan's research reconstructed the vital presence of indigenous women devoted to the petty trade of chicha or corn beer, bread, and other goods and their small-scale credit network until I 700 , while Paulina Numhauser studied the business of coca leaves among the "mujeres indias" in Potosí in the sixteenth century and its relations to their production in Cuzco. ${ }^{4}$ Both authors remind us about the female face of Potosí and, clearly, there was a shift from male workers of the mines to female vendors in the urban markets of the mines.

In recent years, my research on the silver mines, based on the archive of Potosí, the National Archive of Bolivia, the Archive of Buenos Aires, and the Archivo de Indias in Seville, revealed two important aspects not previously taken into account. 5 First, that instead of considering the existence of two completely different groups, with mitayo workers identified as unfree workers and minga workers as free workers, ${ }^{6}$ we should think about two closely

Labor in Potosí, I545-I650 (Albuquerque NM, I984); Jeffrey Cole, The Potosí Mita, I 573-I700: Compulsory Indian Labor in the Andes (Stanford, CA, 1985 ) for the early periods; and Rose Marie Buechler, Gobierno, Minería y Sociedad. Potosí y el "Renacimiento" Borbónico, $1776-1810$ (La Paz, 1989); Enrique Tandeter, "Forced and Free Labour in Late Colonial Potosí", Past and Present, 93 (1981), pp. 98-136; and idem, Coacción y Mercado. La minería de la plata en el Potosí colonial, I692-I826 (Buenos Aires, 1992). The list of articles about the mita and Potosí is, however, much longer.

4. Brooke Larson, "Producción Doméstica y trabajo femenino indígena en la formación de una economía mercantil colonial”, Historia Boliviana, III/2 (1983), pp. I73-188; Bianca Premo, "On Currents and Comparisons: Gender and the Atlantic Turn in Spanish America", History Compass, (2010), pp. 223-237; Jane E. Mangan, Trading Roles. Gender, Ethnicity and the Urban Economy in Colonial Potosi; Paulina Numhauser, Mujeres indias y señores de la coca: Potosí y Cuzco en el siglo XVII (Madrid, 2005).

5. Rossana Barragán, "Potosîs Silver and the Global World of Trade (Sixteenth to Eighteenth Centuries)", in Karl H. Roth (ed.), On the Road to Global Labour History: A Festschrift for Marcel van der Linden (Leiden [etc.], 2017), pp. 6I-92; idem, "Dynamics of Continuity and Change: Shifts in Labour Relations in the Potosí Mines (I680-I8I2), International Review of Social History, 6r: Special Issue 24 (2016), pp. 93-II4; idem, "Working Silver for the World: Mining Labor and Popular Economy in Colonial Potosí", Hispanic American Historical Review, 72:I (2017), pp. 193-222.

6. Bakewell, Miners of the Red Mountain, used the terms "forced workers" and "draft system" for mitayos. The opposition between forced and free labour is most pronounced in Enrique Tandeter, 
intertwined labour positions. In order to understand this statement, it is important to recall that the mita system, characterized as a form of draft labour, corvée labour, or unfree labour, consisted of shifts to work one week out of three throughout one year. Some of the mitayos or "unfree workers" could then be engaged as "free workers" in the mines in their "rest" (buelga) weeks. This is why the ensemble could also be understood as a system that combined low-wage corvée or mita with better paid free work. Second, it is no longer possible to associate the production of silver only with the output of the recognized Mine and Refinery Guild (Gremio de Azogueros), ${ }^{7}$ which received its yearly quota of mitayo workers from the authorities of the Spanish Crown. Silver sales by thousands of people known as $k$ 'ajchas and trapicheros in the second half of the eighteenth century change our perspective on silver production and marketing in Potosí. $K^{\prime}$ ajchas and trapiches constituted a parallel sphere of ore extraction and its conversion into silver and, therefore, they could be identified as an informal sector. The k'ajchas were people who worked underground during the weekends and could be involved in the trapiches or rudimentary mills. ${ }^{8}$ Both sold their silver to the Bank managed by the Spanish Crown. This meant that they were paying their tax and, in this sense, their silver was not illegal or outside the law or the norms. This circuit of production and sales corresponds, then, to a wide arena of artisanal and small-scale production, little known in the whole of Spanish America for the colonial period. More important and unnoticed in historiography, however, is the fact that amidst the group of small vendors of silver to the Bank throughout the second half of eighteenth century there were at least ten per cent of women, Indian, and mestizo people (a person of combined descent, generally of Spanish and Indian origin).

These aspects, grounded on old and new sources, enable a shift in the focus from women's other activities (analysed by Mangan and Numhauser) to women's mining activities. In this sense, it is important to go beyond the view that mining consisted only of underground hard labour, as Dana Velasco Murillo wrote, criticizing the relegation of women to the background, considering them as peripheral figures. Calling for a broad understanding of labour, she pointed out their importance in the multiple endeavours

\footnotetext{
"Forced and Free Labour in Late Colonial Potosî". In general, there is an agreement on the forced and compulsory character of the mita. However, some scholars, like Paulina Numhauser, consider that Europeans and Indians worked together in the mines "voluntarily", both making a profit from their activities. See Mujeres indígenas y señores de la coca, particularly pp. 20 and I 35 .

7. The name comes from azogue or mercury/quicksilver used in the amalgamation process.

8. On historiography about $k^{\prime}$ ajchas and cooperatives in chronological order: Arzans, Mendoza, Hanke, Tandeter, Abercrombie, Rodríguez, see Rossana Barragán, “K’ajchas, Trapiches y plata en el cerro de Potosí”, Anuario del Archivo y Biblioteca Nacionales de Bolivia 20I4, pp. 273-320.
} 
performed above ground. ${ }^{9}$ Allison M. Bigelow, on the other hand, underlined how the analysis of macro-level structures hides and renders invisible how women made a living in the mines and how the language of mining "obscured women's technical knowledge and labour". ${ }^{1 \circ}$

In this article, I will therefore focus on women directly involved in the activities of silver production, refining, and trade. Why is this so important? I claim that it is not just a matter of saying that women were also present in the work of the mines. ${ }^{\text {II }}$ To carefully scrutinize women's involvement in mining activities leads us to reconsider two important topics. First, to historicize what is now called "informal" labour and Artisanal and Small-Scale Mining (ASM) associated with precarity and in which women are so important today, as we have seen in the introduction to this Special Theme. ${ }^{\mathrm{I} 2}$ Second, to re-read the history of mining in Potosí with particular attention in order to obtain a broad and more complete perspective of changes over time and of the position of women in the different settings and periods, illuminating the complex world of work in these mines. Both aspects allow us to realize how male-gendered the sources and the studies based on them are, which rendered these women (and men) invisible, opening up questions for further research.

Although informal work and precarious work are related, they do not refer to the same phenomena. Precarious work is identified with instability at work, in comparison with a full-time "standard employment model" during the capitalism of the twentieth century, and with activities without a regular income. More importantly, from feminist perspectives, precarity has been linked to women's work. ${ }^{13}$ However, the definition of precarity as insecure

9. See Dana Velasco Murillo, "Laboring Above Ground: Indigenous Women in New Spain's Silver Mining District, Zacatecas, Mexico, 1620-1770", Hispanic American Historical Review, 93:I (2013), pp. 3-32, 7 .

I०. Allison Margaret Bigelow, "Women, Men, and the Legal Languages of Mining in the Colonial Andes", Ethnohistory 63:2 (2016), pp. 35 I-380. She published, at the end of her article, a list of one hundred cases of women involved in mining between I 599 and I $80 \mathrm{I}$.

I I. The present study does not take into account the important role of the wives of workers as providers of food for their husbands and as caretakers for their family. In other words, the significant world of the reproduction of labour power.

I 2. Some common characteristics of ASM include activities that range from informal to formal and may or may not be well-organized; linked to rural poverty with a lack of alternatives that would provide better opportunities for income generation, sometimes seasonal, labour intensive, and with low levels of technology.

I3. See Eloisa Betti, "Precarious Work: Norm or Exception of Capitalism? Historicizing a Contemporary Debate: A Global Gendered Perspective”, in E. Betti, K. Miller (eds) The Power of the Norm. Fragile Rules and Significant Exceptions. IWM Junior Visiting Fellows' Conferences, Vol. 35 (Vienna, 20I6) and "Historicizing Precarious Work: Forty Years of Research in the Social Sciences and Humanities", International Review of Social History, 63 (2018), pp. 273-319. For the history of precarious work, see the important article by Christian de Vito, "Labor Flexibility and Labor Precariousness as Conceptual Tools for the Historical 
employment or income corresponds to the process of labour in Europe in the twentieth century. Precariousness or precarity, like dangerous, hazardous, or risky work, was inherent to labour conditions and could be just a matter of "degrees". Informal labour, on the other hand, refers to distinct activities not related to the formal sector; to a subordinated economy that reduces input and labour costs and, in this sense, is linked to the formal sector; or to entrepreneurs trying to avoid costs, regulations, and taxation. ${ }^{14}$ My point of departure regarding informal and precarious work, based on my experience of living in a country like Bolivia, but also based on Breman, Van der Linden, and Munck, is that informality "has been always the dominant mode of employment in the developing world", and that the "type of work described by the term precarity" has been the norm in the Global South, involving power relations and a gender division of labour, as Federicci underlined. ${ }^{\text {Is }}$ Women in the cities were, and still are today, in informal employment (also known as cuenta propia $=$ self-employed or for their own labour) and in precarious jobs.

Grounded on these statements, this article argues that formal and informal employment, as precarity, developed simultaneously because they exist in relation to one another. In the first part of this paper, I will reconstruct how indigenous women played a crucial role in the early period of Potosí, between I 545 and I 575 . Indian people were under different kinds of sharecropping arrangements, silver was obtained through pre-Hispanic technologies, and, in the metal market, women were predominant. It was a time when everyone made more profit from all these activities. The introduction of a new refining method to obtain silver after I 570 implied the organization of a system of large-scale work and the emergence of unfree and free wage workers inside the mines and in the refining mills (ingenios) that used abundant water and mercury (amalgamation). Although the underground work was a male sphere, silver mining labour was not limited to this task. In the second part, I underline the complex process of work and a division of labour that has frequently been underrated. When this is taken into account, as part of specialized work

Study of the Interaction among Labor Relations”, in Karl Heinz Roth (ed.), On the Road to Global History. A Festschrift for Marcel van der Linden (Leiden, 2017).

I4. See Martha Alter Chen, "The Informal Economy: Definitions, Theories and Policies”, WIEGO Work Paper No. I, 20I2, available at: http://wiego.org/sites/wiego.org/files/publications/files/ Chen_WIEGO_WPr.pdf; last accessed 20 June 20I8. The author gives a good overview of the four schools (Dualist, Structuralist, Legalist, and Voluntarist) about informal employment and informal economy.

I 5. Jan Breman and Marcel Van der Linden, "Informalizing the Economy: The Return of the Social Question at a Global Level”, in Development and Changes 45:5 (2014), pp. 920-940, 926; Ronaldo Munck, "The Precariat: AView from the South", Third World Quarterly, 34: 5 (2013), pp. 747-762, 752; Silvia Federicci, "Precarious Labor: A Feminist Viewpoint" (2006), available at: https:// inthemiddleofthewhirlwind.wordpress.com/precarious-labor-a-feminist-viewpoint/; last accessed 20 June 2018. 
that has been minimized, women become visible. Finally, in the third part, I analyse how women participated in the important activities of refining ore in rudimentary mills or trapiches in the eighteenth century, selling the silver to the Bank.

\section{THE MINES IN THE EARLY PERIOD OF POTOSİ AND WOMEN IN THE SMELTING PROCESS ( GUAYRA) AND IN THE METAL MARKET (GATO)}

As in most European territories, in those conquered and established as Spanish America the crown claimed special rights in the mines and in the production of metals, known as jus regale, meaning that part of the production should be handed over to the Royal Treasury, and that the King was the legal owner of the treasures below the ground, having the right to award concessions. ${ }^{16}$ However, the practices and the laws issued in Spanish America were diverse, particularly throughout the sixteenth century. ${ }^{17}$ There is scarce knowledge about Potosí after its "discovery" ${ }^{8}$ in I 545 and before the great changes introduced from I 570 onwards. In I 574 , the rules established the royal right that allowed the King to grant permissions over the mines to his vassals and subjects, whatever their situation: Spaniards, Indians, and foreigners could exploit them in exchange for a tax on production. ${ }^{19}$ A published and very important source written by an important mine-owner, Luis Capoche (Relación general

I6. Christoph Bartels, "The Administration of Mining in Late Medieval and Early Modern Europe", in Nanny Kim and Keiko Nagase-Reimer (eds), Mining, Monies and Culture in Early Modern Societies, (Leiden, 2013), p. I 17. See also Numhauser, Mujeres indígenas, pp. 103-105.

17. Castilian norms were applied in several places, although the laws also had a local character. Miguel Molina Martínez, "Legislación minera colonial en tiempos de Felipe II", in Francisco Morales Padrón (ed.), XIII Coloquio de Historia Canario-Americana, VIII Congreso Internacional de Historia de América (AEA) I998, pp. IoI4-Iors; Demetrio Ramos, "Ordenación de la minería en Hispanoamérica durante la época provincial (siglos XVI, XVII y XVIII)", in La minería hispana e iberoamericana: contribución a su investigación histórica: estudios, fuentes, bibliografía (León, 1970), p. 386.

I 8. Tristan Platt and Pablo Quisbert, "Tras las huellas del silencio: Potosí, los Incas y Toledo", Runa 31:2 (2010), pp. I I 5-I 2 .

I9. “ [...] todas las personas de qualquier estado, condición, preeminencia, o dignidad, españoles e indios, nuestros vasallos, puedan sacar oro, plata, azogue y otros metales por sus personas, criados o esclavos en todas las minas [...] que hallaren”. Ley j. Tit. XIX, Recopilación de leyes de los reinos de las Indias, vol. 2 (Madrid, I79I), p. 68. It was also explained that the Indians could hold and exploit gold and silver mines in the same way as the Spaniards. Ley XIIIJ, I55 I, I 563, I575, in Recopilación, vol. 2, p. 7I. "De los Descubridores, registros y estacas, Ordenanza I" de las Ordenanzas de Minas, Francisco de Toledo, Relaciones de los Virreyes y Audiencias que han gobernado el Perú. T. I. Memorial y Ordenanzas de Francisco de Toledo, (Lima, I 867). The Rules of La Gasca in I5 50 in Potosí sanctioned by the Audiencia of Lima; the Rules of Polo de Ondegardo in I 562, and those of Toledo in I 574, ratified the royal ownership of the soil, introducing a series of regulations. Molina Martinez, "Legislación minera colonial”, pp. Iог4-Io 5. 
de la villa imperial de Potosi, I 85 ), listed more than ninety-three seams (vetas) in the mountain of Potosí and in each one there was a variable number of mines and people, from seventy-eight in the seam called Veta Rica, for example, to just one person in some other seams. This recalls the system of holding shares in the mines in late medieval and early modern Europe. ${ }^{20}$ Therefore, a high number of people were recorded, over 500, among them twenty-three Indians, including some Incas and other people from Cuzco and the surrounding areas, although they do not appear as owners in the following decades.

In this early period, Indian people had more access to the underground, and not just as "workers". Even Viceroy Toledo, who organized the mita system, granted a concession to operate a mine of sixty varas, almost fifty metres, "held in common" for the caciques and for the communities destined to pay the taxes and the expenses in mita labouring. The caciques or noble Indian leaders were granted an additional eighty varas. This same provision applied to the ordinary Indians although, at the same time, it established that "more Indians cannot be granted concessions" without there being enough for the Spaniards. ${ }^{21}$

Important fragments of published and unpublished sources reveal different kinds of labour arrangements, "workers", and payments. Some Indian people had to produce an amount of silver for their masters (amos), and beyond that amount they could keep ore for themselves. They could be yanaconas or people without any link to an Indian community but attached, personally, to certain individuals, Spaniards, or Indian caciques. ${ }^{22}$ There were also encomienda Indians going to work in order to pay their taxes to the Spanish encomenderos. Moreover, several agreements (conciertos) existed between the mine owners and indigenous peoples, which I characterize as sharecropping. There was, too, a leasing of some mines to the Indians who worked the seams with other workers at their own cost. ${ }^{23}$ In all of these cases, Indian workers

20. Bartels, "The Administration of Mining in Late Medieval and Early Modern Europe", p. I 20; Luis Capoche Relación general de la villa imperial de Potosí (Madrid, I 85 -1959), pp. 79-102. 2 I. Vara $=$ linear measurement of 0.838 metres; see Bakewell, Miners of the Red Mountain, p. 198. Título I, Ordenanza V, Ordenanzas para las minas de plata de Potosí y Porco, I 574, in Francisco de Toledo, Disposiciones gubernativas para el Virreinato del Perú, I 569-I 574 (Sevilla, I986), p. 307. Bakewell noted that the Cabildo of Potosí complained in this period that Indians were taking mine bags full of the best smelting ore, Bakewell, Miners of the Red Mountain, p. 79.

22. About yanaconas, see Laura Escobari de Querejazu, Caciques, yanaconas y extravagantes. Sociedad y educación colonial en Charcas, s. XVI-XVIII (La Paz, 2012); Josep Barnadas, Charcas, Orígenes históricos de una sociedad colonial (La Paz, 1973), p. 367; Juan de Matienzo, Gobierno del Perú (Buenos Aires, [1567] 1910), pp. I8-19.

23. See Bakewell, Miners of the Red Mountain, pp. 36-38, and Josep Barnadas, "Una polémica colonial: Potosí, I 579-1 584", Jahrbuch für Geschichte Lateinamerikas, Anuario de Historia de America Latina, I0:I (1973), pp. 16-70, particularly the transcriptions of testimonies at the end of the article that illuminate the variety of labour arrangements. 
obtained ore as their payment and they also refined it by themselves or through others.

A letter to the King in I 578 explained that, although the mines were not owned by Indians, these mines were, in fact, theirs because they used to buy their ore from their owners and smelt it, making big profits. ${ }^{24}$

Silver was obtained through smelting in indigenous wind-blown furnaces made from stones and clay (traditional pre-Hispanic technology called guayras). ${ }^{25}$ These furnaces used the wind of the mountains and the fuel was an evergreen moss that grew at high altitudes (yareta or azarella compacta known as "the firewood of this earth"), llama dung, and a small shrub or special tree (kehuiña, polilepsis incana). ${ }^{26}$

If men were working underground, it is possible to imagine that more women were involved in the smelting process in the mountains in the more than 6,000 wind-blown furnaces or guayras. ${ }^{27}$ Women's involvement could be even more relevant when men became involved as mitayo workers under wage relationships after 1575 . Women also appeared amongst the main sellers of ore. In Potosí, as in a number of cities of Spanish America, the plazas were the main market centres. One of the most important in Potosí was the core indigenous Plaza del Metal or Gato (in Aymara language khatu and in Quechua language, khjato), where around 400 to 500 people traded ore and silver, particularly from Thursday to Saturday. ${ }^{28}$

This special trade market (Gato) was nurtured by multiple channels. First, from the production of the concessions granted to the communities and to their leaders or caciques, as mentioned above, responsible for the organization and delivery of mitayos from their provinces in Potosí. Second, from the ore

24. "aunque estas minas no heran suyas, lo heran en su aprovechamiento [...] porque estos compraban los metales de los españoles en mucho menos precio de su valor”, Carta de Bravo al Rey, in footnotes I 30 and I 3 I of Barnadas, Charcas, pp. 374-375.

25. C. Cohen, T Rehren, and M. Van Buren, "La huayrachina por dentro y por fuera: un estudio arqueo-metalúrgico de la tecnología de fundición de plomo en Porco-Potosí”, in P. Cruz and J. Vacher (eds), Mina y Metalurgia en los Andes del Sur, desde la época prehispánica hasta el siglo XVII (Sucre, 2008), pp. 29-56; Pablo Cruz and Pascale Absi, "Cerros ardientes y huayras calladas. Potosí antes y durante el contacto”, in Ibid, pp. 9I-IOI; Florian Téreygeol and Pablo Cruz "Metal del viento. Aproximación experimental para la comprensión del funcionamiento de las wayras andinas", Estudios Atacameños, 48 (2014), pp. 39-54.

26. García Llanos, Diccionario y maneras de hablar que se usan en las minas y sus labores en los ingenios y beneficios de los metales (Lima, [I6I I 2009), p. I2; Thilo Rehren, "The Production of Silver in South America”, Archaeology International I 3-I4 (2009-20I I), pp. 76-83, p. 80; Modesto Bargalló, La minería y la metalurgia en la América Española durante la época colonial (Fondo de Cultura Económica) (México, I955), p. 97. Bakewell, Miners of the Red Mountain, specifies the use of kewina, p. 7. An anonymous writing of 1603 says that human faeces were also used after a drying process: "Descripción de la Villa y minas de Potosí", I603, in Jimenez de la Espada (ed.), Relaciones Geográficas de Indias, (Madrid, 1965), p. 384.

27. Capoche, Relación General, pp. 108-I I I.

28. Ibid., p. I6I. 
paid as part of the sharecropping arrangements and wages. Third, from the petty trade and rescate (rescue and gathering) carried out by some individuals who used to buy ore from people who were in the bowels of the mountain. Fourth, from the workers, mitayos, or coerced workers, and mingas or free workers, ${ }^{29}$ who gathered every Monday to climb up to the mountain where they stayed until Saturday afternoon. Some of their wives or other women made the food for them once a week. Workers used to buy provisions with ore, particularly bread, candles, and wine, or comidas (food dishes; the term is a generic one but it is also used for ready meals) from women who carried these goods up there every week. ${ }^{3 \circ}$ It seems, too, that some women ran small shops very close to the mountain, where they sold coca leaves and bread in exchange for ore. ${ }^{3 \mathrm{I}}$ There were also people paid by specialist traders to convince Indians to sell the ore that they were extracting, giving them coca, food, and other products..$^{32}$ Finally, there were many Indian palladores who used to search for ore in the tailings, and there was a special group, the Indian Uruquillas, who were particularly devoted to this task, living in the same mountain.

This metal market, authorized by the same Viceroy Toledo, was called into question from I 579-I 584 , as analysed by Barnadas. Owners of the mines, refiners, and authorities characterized the ore sold by Indians as theft and Larson refers to them as "silver pirates". ${ }^{33}$ The testimonies presented to the court by different actors of that time are invaluable in their detail. Several Indians testified that they were paid in ore, as we have noted above. ${ }^{34}$ Although it has been mentioned that, from I 574 onwards, cash wages would have prevailed and mitayos could choose not to work the quarter of a mine as was their right, ${ }^{35}$ it is possible to think that a tradition of taking ore or of being paid in metal still existed and the rescate or trade in ore never disappeared. In 1585 , Capoche described this important market as a place where more than 400 to 500 people were seated on the floor, selling in rows, three days every week, particularly Thursday, Friday, and Saturday. The wide variety of ores were

29. I analyse the intimate interrelationship between mita and minga workers in Barragán, "Working Silver for the World".

30. "llevan comida el miércoles para toda la semana" (p. 36); "los venden a otros yndios por pan y vino, candelas y otras cosas de comida que llevan al cerro" (p. 50 ); “con los minerales se compran y se venden en el cerro por comidas" (p. 55). Documents from i 579-1580, in Barnadas, "Una polémica colonial”. See also Jane Mangan, Trading Roles, p. 33.

31. Capoche, Relación General, p. 165.

32. Ibid. pp. I $8 \mathrm{I}-\mathrm{I} 82$.

33. Larson, "Producción Doméstica y trabajo femenino indígena", p. I 80.

34. Testimonies in Barnadas, "Una polémica colonial”, pp. 32-37. See the important Jesuit intervention in the discussion on P. Numhauser, "Contradicciones en la política de evangelización en el Perú colonial del siglo XVI. Algunas consideraciones”. Cristianesimo nella Storia, 32:I (201 I), pp. $7 \mathrm{I}-90,80-82$.

35. Bakewell, Miners of the Red Mountain, pp. 77 and 79. 
sold in particular sections in the market: rich ore called tacana; ore mixed with quicksilver, common ores, etc. ${ }^{36}$

If most men were working under different situations on the mountain, women must also have been more involved in feeding the guayras to smelt and to sell ore in the street market. ${ }^{37}$

\section{THE SILVER INDUSTRY AFTER I 575 AND THE PRESENCE OF WOMEN}

Significant changes were introduced by the Viceroy Francisco de Toledo between 1572 and 1576 after a reduction in production due to the scarcity of high-grade metals. The indigenous techniques leading to the smelting were replaced, to a large extent, by the amalgamation process (the blending of pulverized ore with mercury), which became the main technology for refining silver. The process required the provision of mercury, coming from the mine of Huancavelica (in Peru), water for the refining mills, and an important contingent of labour power of around I 2,000 to I 4,000 male workers, between eighteen and fifty years of age, going to Potosí for a period of one year under the leadership of local Indian authorities (caciques or curacas).

The main unit of production was now the ingenio or silver refining plant where the ore had to be milled to a fine powder and subsequently refined through amalgamation. The mills were built in Potosí from I 572 and, in I 576, there were 108 ingenios or mills: twenty-two driven by manpower; twenty-two by animals (horses and mules); and fifteen by water. The mean production per day per mill was 9.37, I9. I I, and I 55.30 quintales, respectively (I quintal is equal to forty-six kilos or Ior pounds). Although the water mills were expensive, they produced much more silver, becoming dominant by the end of the sixteenth century. ${ }^{38}$

The technological change and the measures taken by the Crown had deep consequences. Peter Bakewell pointed out that "the Spanish took hold of the silver refining excluding [...] the Indian from his central position" that they previously had. ${ }^{39}$ Carlos Sempat Assadourian argued that these changes led to an almost absolute concentration of the means of production in the Spanish people with regard to both the extraction and the refining process. In other words, through the rules and practices of ownership, through technology, and particularly through the recruitment and assignment of labour,

36. Capoche, Relación General, p. I6r.

37. Friar Ocaña wrote that women smelted the ore that they received.

38. Peter Bakewell, "Technological Change in Potosí: The Silver Boom of the I 570 's”, Jabrbuch

für Geschichte Lateinamerikas - Anuario de Historia de America Latina, I 4:I (I977), pp. 57-77.

39. Ibid. p. 77. 
a small group of Spanish entrepreneurs, the azogueros, would have been privileged. In I 575, the Viceroy Toledo divided the whole mita (I 2,000 to I 4,000 workers) into three parts, with two thirds being in buelga or rest and one third working. With this system, he assigned 3,6 is Indians every week to 234 mine owners and silver refineries. ${ }^{\circ}{ }^{\circ}$ In 1585 , Capoche, a mine and mill owner himself, wrote that every mill with two milling assemblies (or double-headed mill), received fifty Indian mitayos from the Crown each week, while every mill with one head received thirty-two Indians, and an animal mill (horse or mule driven) around twenty-two Indians. ${ }^{4 \mathrm{I}}$ In I 603, there were just fifty azogueros or owners of silver refining plants (ingenios) in Potosí and no more than twenty in the adjacent towns. ${ }^{42}$

The indigenous people who, prior to i 570 , could have more earnings and profits through share cropping arrangements, with more space to manoeuvre, henceforth became coerced wage workers (mitayos) or wage free workers (mingas). Sempat Assadourian, referring to the writing of Capoche from the sixteenth century, considered that the indigenous population suffered from degradation because they were subordinated to a wage system. Capoche wrote that "the invention of [the procedure of amalgamation with] quicksilver deeply saddened [Indians] as it deprived them of their profit, and the only possibility they had to sustain themselves [...] having owned all the past wealth". ${ }^{43}$

At this juncture, it is important to underline three important points. First, that historiography focused more on the dominant form of ownership and refining (ingenios of azogueros) from the end of the sixteenth century and on these units working with mitayos, obviating other forms of production. Second, that the mitayos used their rest weeks to work as free workers, or mingas, or as independent people who could participate in diverse modalities of silver production, as mentioned above. In this sense, Van Buren showed, on the one hand, how the indigenous population could use appropriated

40. Bakewell, Miners of the Red Mountain, p. 69.

41. Capoche, Relación General, p. i 8 , and the list on p. i 19.

42. Bakewell, Miners of the Red Mountain, pp. 20-2 I. In I692, there were only twenty-seven mill owners who received I, 3 I 0 Indian mitayos every week, Archivo General de la Nación, Buenos Aires, Padrones Potosí I 259. There is no special book devoted to these mine guilds and azogueros. Bakewell wrote about one of the richest of them in the second half of the seventeenth century. Antonio Lopez de Quiroga (Industrial minero del Potosí colonial), (Potosí, 1975). Tandeter (Coacción y mercado) and Buechler (Gobierno, Minería y Sociedad) made important contributions to their study of the eighteenth century. Their complex evolution over time, their debts to the Spanish Crown and to the silver merchants are important topics not completely analysed by the historiography.

43. In Carlos Sempat Assadourian, "La producción de la Mercancía Dinero en la formación del Mercado interno colonial”, Revista Economía, I:2 (1978), pp. 9-56, 29, available at: https://econpapers.repec.org/article/pcppucrev/y_3ai979_3ai_3aO2_3a9-56.htm, last accessed I9 September 2019. 
technology to obtain small amounts of silver with great creativity. ${ }^{44}$ On the other hand, the data I analysed about k'ajchas and trapiches shed light on a sphere of production and sales in the eighteenth century, although they may have existed earlier. It is thus possible to imagine that some old and new techniques may have been mainly in the hands of women, because men were recruited as unfree and free workers in the mines. Third, that the labour process became much more complicated with women participating in it.

Let us concentrate here on the labour process. I argued, in another work, that the production of silver is generally considered to be a simple process of extraction. ${ }^{45}$ The case of Potosí shows, however, that the ore went through a long procedure before it was transformed into pure silver.

The process can be divided into at least six stages underground (in the mines) and above ground: ${ }^{6}$ ore extraction; its selection; trituration of minerals; amalgamation; washing of the mixed mineral; and distillation. ${ }^{47}$ In all these steps, the work was in the hands of the Indian population, unfree (mita), and free (minga) workers.

In the first stage, underground, all workers were men and mainly ore cutters or barreteros, primarily free workers, and those who carried the ore out (apiris), who were unfree and free workers. The second stage was the selection of the ore above ground. After this careful phase, the selected ore was prepared and transported by llamas led by their owners (cumiris) from the mountain to the refining mills (ingenios). The ingenios were rectangular constructions (Figure 2) that enclosed the large and open spaces used in the different stages in the process of conversion of ore into silver, the mill, and the necessary storage rooms. Before the amalgamation, the selected minerals had to be crushed. Then, the fourth stage, or the process of amalgamation, could start.

Water was key to this process and the amount of each element to be blended was the responsibility of the refiner, a Spaniard or a mestizo. The mixing in Potosí was frequently undertaken in special boxes. Each box held fifty quintales of flour ( 5,000 pounds), five of salt, mercury (six to ten pounds

44. Mary van Buren and Claire Cohen, "Technological Change in Silver Production after the Spanish Conquest in Porco, Bolivia”, Boletín del Museo Chileno de Arte Precolombino, i 5:2 (2010), pp. 29-46, 44 .

45. See Rossana Barragán, "Extractive Economy and Institutions? Technology, Labour and Land in Potosí, the Sixteenth to the Eighteenth Century)”, in Karin Hofmeester and Pim de Zwart (eds), Colonialism, Institutional Change, and Shifts in Global Labour Relations (Amsterdam, 2018), pp. 207-237.

46. See Velasco Murillo "Laboring above Ground".

47. Garavaglia speaks of five stages. I added one stage. See Juan Carlos Garavaglia, "Plata para el Rey. Tecnología y Producción en el Potosí colonial”, in Juan Marchena (ed.), Potosí, plata para Europa (Sevilla, 2000), p. I29. 


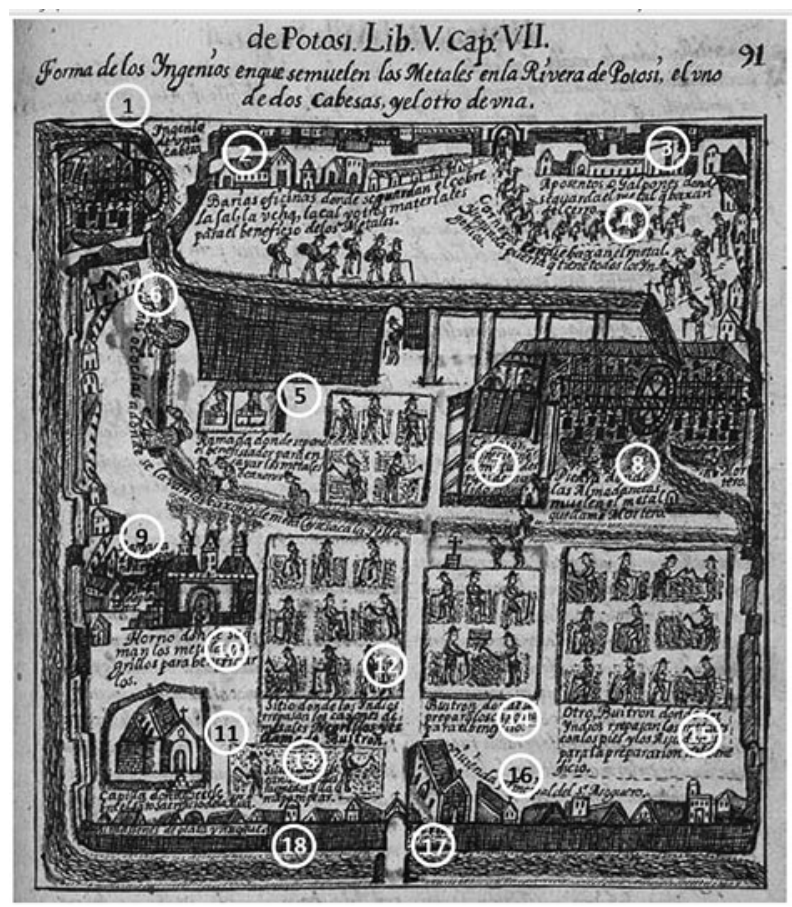

Figure 2. The activities within an Ingenio, according to Arzans Orsúa y Vela, Historia de la villa Imperial de Potosí (eighteenth century). ${ }^{8}$

I. Waterwheel with one milling assembly (cabeza de ingenio)

2. Storage rooms for copper, salt, dung, lime, and other materials

3. Storage rooms for the ore arriving from the mountain

4. Llamas used for the ore's transport. Second door of the ingenio

5. Shelter for the refiner who does the assays for the amalgamation

6. Small pools or ponds to wash the boxes to obtain the mix of silver and mercury

7. Wire screen to sieve the ore after it has been crushed

8. Mortar where the stamps crush the ore

9. Shelter

Io. Furnaces to prepare the ore called negrillo

I I. Chapel for the celebration of the mass

I2. Place where the Indians mix the ores in boxes

I3. Place where the wet ores are dried (pampear)

I4. Place where the ore boxes are prepared

I 5. Buitron or place where the Indians remove and mix the ores with mercury, using their feet (repasiris)

I6. Main house of the owner

I7. Main door

18. Warehouses of silver and mercury

48. Bartolomé Arzáns de Orsúa y Vela, Historia de la Villa Imperial de Potosí, edited by Lewis Hanke and Gunnar Mendoza, 3 vols (Providence, 1965). 
per quintal of ore), copper sulphate (magistral), and iron. ${ }^{49}$ The dough was removed and mixed by the workers using their feet (repasiris) over several (three or more) weeks until the mercury was completely incorporated in the mix. ${ }^{50}$ The boxes were sometimes submitted to heat. ${ }^{51}$

After the amalgamation, the fifth stage could start. This was the washing process that used a stream of water. The light particles were washed while the heavy parts of the mix, consisting of the amalgam of mercury and silver, settled down, constituting the pella. Habitually, several vats and settling pools were used in series to maximize the recovery of the mercury amalgam. ${ }^{52}$ The pella was then squeezed into bags to obtain a solid dough.

Women were important in at least two of these stages: in the process of selection of minerals (pallar) and in the task of sieving the crushed ore. Pallar was a Spanish term originating from the native language Quechua meaning to select. In a specialized mining dictionary from the seventeenth century, there were at least three activities under the name of pallar. The first one was the cleaning and selection of the minerals that were taken from underground and moved to open spaces or patios called cancha in front of the mine entrances. The second activity was the search for good minerals in the mineral tailings (desmontes) sold to people that used them in the mills. Finally, the third one was counting the minerals obtained. There are few sources that specify who was doing this work. One of them, from $\mathrm{I}_{603}$, held that the selection of minerals was done by boys, elderly people, and women..$^{53}$ Another source said that there were more than a thousand people involved in this task. ${ }^{54}$ A Spanish Friar gave this description:

[...] Indian women also look for the rocks which are discarded around the mouths of the mine, which is called "pallar", that is, to break them up and choose those of value and separate them from the rest. And these are all sold at mid-day in Potosí. And before that hour, no Spaniard can buy anything from an Indian, and this is so that the Indians have a chance to buy these metals, as there are many Indians who buy them for their furnaces. 55

Despite this selection process being crucial, it seems to have been underevaluated. The differentiation at that time was based mainly on the colours

49. Bakewell, Miners of the Red Mountain, p. 2 I.

50. Garavaglia, "Plata para el Rey", p. I37.

5. Modeto Bargalló, La minería y la metalurgia en la América Española durante la época colonial (México, I955), pp. I34-135.

52. Bakewell, Miners of the Red Mountain, p. 22.

53. García de Llanos, Diccionario, pp. IOI-IO2.

54. "Descripción de la Villa y minas de Potosí" I603, p. 377.

55. Friar Diego de Ocaña, "The Famous Cerro de Potosí and Customs of Her People” (I 599), quoted by Stephen Ferry, I Am Rich Potosi: The Mountain That Eats Men (New York, I999). The original testimony comes from Relación del viaje de Fray Diego de Ocaña por el Nuevo Mundo (I599-1605). 
of the metals: reddish (paco), blackish (negrillo) or grey (anco or tacana)..$^{56}$ This was an important task because it determined which minerals had to be smelted or amalgamated. The famous scientist of the period, Alonso Barba, stipulated that grey minerals or tacanas should follow the amalgamation process, while others should be smelted (rosicler, cochizo, and soroches). ${ }^{57}$

Another task performed by women and children was sieving minerals in the refineries. Capoche wrote in I 590 that there were women and children doing this as "free workers" and receiving two reales, i.e. half of the amount received by males working as free workers (a coerced worker or mitayo received 3.5 reales per day and a free worker four reales per day). ${ }^{8}$ Other jobs undertaken by women were the collection of fuel (llama dung and other fuels) used for the diverse mining steps and, more importantly, the exploitation of the residues of washed amalgam. It has already been mentioned that a kind of settling pool was used to recover them. These residues were dried, crushed, and burned in order to recover the mercury. Immediately afterwards, the ore was mixed with lime and copper to obtain silver. This business occupied more than 3,000 men and women! 59

Wages in the mines are also important when considering women's labour. Bakewell established that the salary of a male mitayo did not cover the expenses for food and other costs for him and his family: he earned sixty-five pesos for six months but he needed at least 200 pesos, meaning that he had to find an additional i 35 pesos. Not only were the mitayos obliged to work during their rest weeks, but the women and other members of the family also had to find other ways of earning a living. ${ }^{60}$ It is, however, important to bear in mind that the mitayos were allowed to work part of the mines for themselves, meaning that the wages were also in kind, as underlined above. Payment in kind was, in any case, subject to a struggle, particularly between I 579 and I 584. Barnadas showed that the mine owners complained that workers were stealing their ore, although more than sixty-seven Indian testimonies asserted that people known as pongos (Indian mine caretakers) and the mingas or free workers were paid in ore, in addition to the sales that took place on some days

56. García de Llanos, Diccionario, pp. 8 I-85. About the "language of colours" and science, see Allison Margaret Bigelow, “Conchos, colores y castas de metales: el lenguaje de la ciencia colonial en la region andina", Umbrales 29, (2015), pp. I 5-47; and "Women, Men and the Legal Languages of Mining in the Colonial Andes”, Ethnohistory, 63:2 (2016), pp. 35 I-380. Bigelow also analyses the importance of the terms pallar and pallatha.

57. Alonso Barba, Arte de los Metales (Lima, i 817), pp. 83-84.

58. See Capoche, Relación, p. I 22, and Bakewell, Miners of the Red Mountain, p. IoI.

59. "Descripción de la Villa y minas de Potosí" I603, pp. 384 and 376-377. García Llanos, Diccionario, pointed out that women were also busy feeding the furnaces with fire to recover silver remains (p. I 2).

60. Bakewell, Miners of the Red Mountain, pp. I04-105. Larson underlined the importance of the family economy for the colonial and mercantile economy of Potosí: Larson, "Producción Doméstica y trabajo femenino indígena”, pp. I $84-185$. 
outside the mines. ${ }^{61}$ Capoche stated that "on the mountain there were no other monies than the ores" ${ }^{62}$ The qatu or metal market in Indian hands was justified and explained through these modalities prevailing in the mines.

It is important, then, to bear in mind that other forms of refining continued. The information about the sales of silver outside the miners' guild in the eighteenth century leads us to think that parallel circuits could continue to exist throughout the seventeenth century, although they acquired considerable importance and visibility in the second half of the eighteenth century.

\section{WOMEN IN THE TRAPICHES (THE K'AJCHAS-TRAPICHES ENSEMBLE OF SELF-EMPLOYMENT)}

From the sixteenth century, there were different modalities through which workers could receive some ore for their own benefit and, as we have seen, this could also be part of their wages. Throughout these years, the owners of the mines and mills tried to establish whether the workers could keep some of the ore that they extracted for themselves, defining what was allowed and what was forbidden. In general, the Spanish owners accepted that the workers could take some ore as an additional economic compensation and a form of attracting a workforce. However, they also tried to control its extraction.

In previous articles, I analysed the emergence, in the mid-eighteenth century, of a group of people called "thieves" by the mine and mill owners. They were known more generally as $k$ 'ajchas, and this term was used to describe people who extracted ore from the mines, during the weekends, for their own benefit.

The $k$ 'ajchas worked in the trapiches, which were the small-scale ore-processing mills. A trapiche was described as a place where ore was ground up using large rocks, ${ }^{63}$ as opposed to the massive machinery associated with the water-driven hammer of the more elaborate ingenio mill or refinery. It seems that the process in the trapiche resembled the native Indian and Inca practice of grinding ore, called quimbalate by the Spanish. This involved the use of a boulder described as having a "half-moon shape in profile" used to crush the ore placed beneath it (see 'A' in Figure 3). ${ }^{64}$ It is possible that the name was a generic one, involving a variety of possibilities. In any case, in

61. Barnadas, "Polémica", pp. 32-37. Capoche in I 585 , Relación General, mentioned that ores in Indian hands were not stolen but were part of their salary (p. I 5 ). He also explained that the wages in kind paid to the mingas were called corpa (p. I09).

62. Capoche, Relación General, p. I 54.

63. In the Descripción of 1759 (BL, f. 287-289), the trapiche consisted of two large stones: a broad stone of a metre or two in length, which lay flat upon the surface, on which another stone, called a fly wheel, moved rapidly enough to grind the ore. For more on technology, see Barragán, "Ladrones, Pequeños Empresarios o trabajadores independientes".

64. Bakewell, Miners of the Red Mountain, p. 198. 


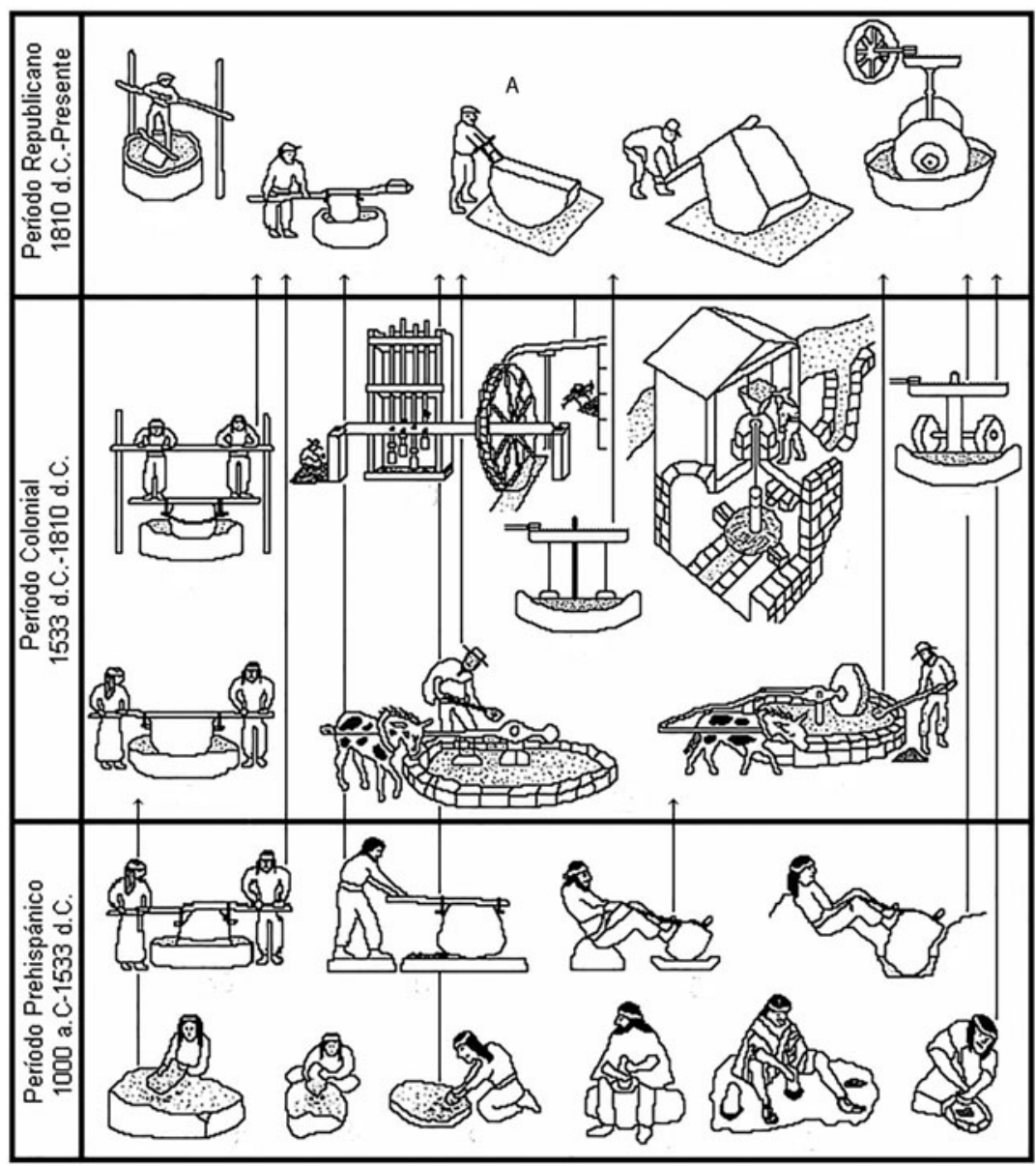

Figure 3. Different kinds of mills, according to De Nigris (201 2). ${ }^{65}$

I735, there is a drawing that clearly shows a trapiche at that time, with the ponds to wash the mix and the furnaces to evaporate the mercury (Figure 4).

In an official inspection in $176 \mathrm{I}-\mathrm{I} 762$, each trapiche was listed with the name of the worker, the number of stones they had (quimbalate) to grind the ore, whether or not they were working with permission, and whether they had been awarded mines. The information shows that the trapiches

65. Mario De Nigris Ricardo, “Los molinos mineros andinos” (2012), available at: https://www. academia.edu/2000342/De_Nigris_M._Los_Molinos_Mineros_Andinos/; last accessed 20 June 2018. 


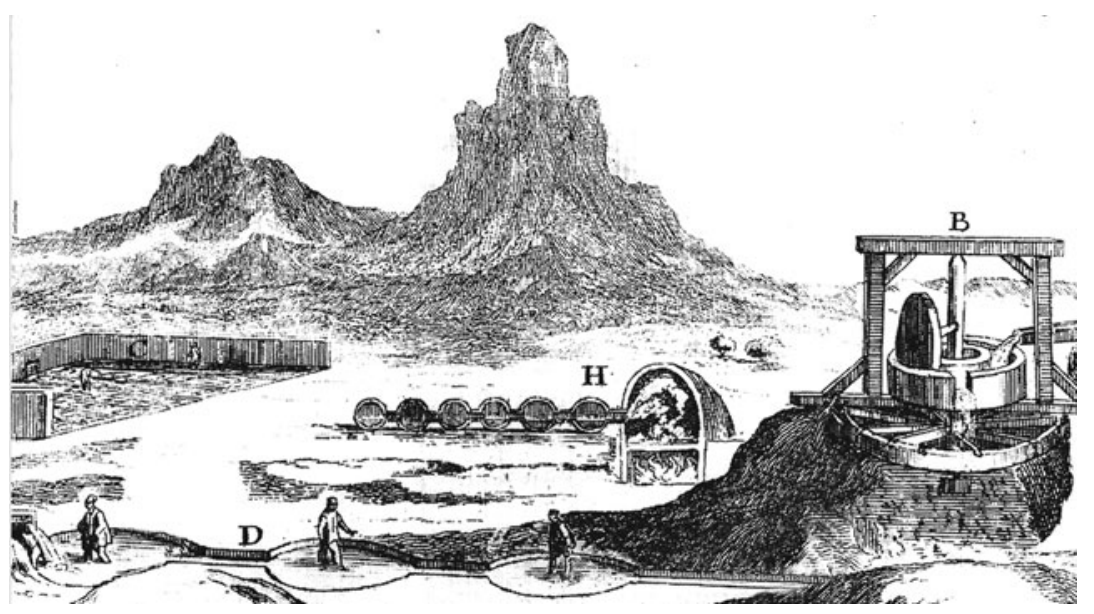

Figure 4. Trapiche, according to Frézier (1732).

In: Relation du voyage de la Mer du Sud aux côtes du ChilI et du Perou et du Brésil: fait pendant les années 1712,1713 E I7I4. Ed. Chez Jean-Geoffrey Nyon; Etienne Ganeu; Jacque Quillau. France: 1716.

$$
\begin{aligned}
& \mathrm{B}=\text { Trapiche or mill to crush minerals } \\
& \mathrm{D}=\text { Ponds to wash the amalgam } \\
& \mathrm{H}=\text { Furnaces to take away the mercury }
\end{aligned}
$$

were experiencing a boom, for more than forty had been established over the previous two years, while only twenty-two of them were more than fifty years old.

The trapiches were scattered throughout the city, which, since the end of the sixteenth century, had a Spanish neighbourhood and parish, around the main church and plaza, and Indian/Native neighbourhoods in other surrounding parishes. Indian people who lived in the city, but also the mitayos with their families who used to come, annually, to work for one year in the mines (mitayo workers), arrived at houses that were within the limits of these parishes. There was a clear hierarchy, ordered according to their ayllu or community of origin. ${ }^{66}$ In the parish of San Franciso el Chico, for example, there were people from the ayllu Chayanta (northern Potosí), Yanaoca (Cusco), and others; in San Pedro, there were the ayllu Colla, Pumachapi, Chacachupi, and Yunguyo, from Lake Titicaca. In the parish of Copacabana, there were other ayllus like Carabuco, an important village in the province of Omasuyos in La Paz, and the ayllu Kachas (Cachas).

One of the most interesting aspects of the 1762 inspection is that it shows us the distribution between Spaniards and Indians and between those different 
Table I. Distribution of Trapiches in the Parishes of Potosi in $176{ }_{1-I 762}$

\begin{tabular}{|c|c|c|}
\hline Trapiches & No. & Women \\
\hline Trapiches of Spaniards (men and women) & 58 & 9 \\
\hline $\begin{array}{l}\text { Trapiches of the natives of the Parish of San Christoval (ayllus } \\
\text { Caracoto, Aymaya, Chaqui, Macari, Pocoata and Mujico) }\end{array}$ & 33 & 5 \\
\hline $\begin{array}{l}\text { Trapiches of the natives of the Parish of San Francisco el Chico } \\
\text { (ayllus Yanaoca, Quero Marca, Compabata, Chullpa, } \\
\text { Chayanta, Indiganga, Sicoya) }\end{array}$ & 18 & 1 \\
\hline $\begin{array}{l}\text { Trapiches of the natives of the Parish of San Pedro (ayllus Colla, } \\
\text { Pumachapi, Chacacupi, Yura, Juliaca, Pichigua, Yunguyo, } \\
\text { Cachas }\end{array}$ & 21 & 5 \\
\hline $\begin{array}{l}\text { Trapiches of the natives of the Parish of Copacabana (ayllus } \\
\text { Cachas, Urinsaya, Carabuco, Yanaoca) }\end{array}$ & 21 & 5 \\
\hline $\begin{array}{l}\text { Trapiches of the natives of the Parish of Concepción (ayllus } \\
\text { Acauiri, Asillo, Jesús de Machaca, Azángaro, Orurillo, } \\
\text { Collana, Acaniri) }\end{array}$ & 19 & 0 \\
\hline $\begin{array}{l}\text { Trapiches of the natives of the Parish of San Juan (ayllus Hilave, } \\
\text { Nungua, Acora) }\end{array}$ & 3 & 0 \\
\hline $\begin{array}{l}\text { Trapiches of the natives of the Parish of Sebastián (ayllus } \\
\text { Pumacarcha, Pueblo nuevo) }\end{array}$ & 5 & 1 \\
\hline $\begin{array}{l}\text { Trapiches of the natives of the Parish of San Pablo (ayllus Sicoani, } \\
\text { Santiago, Guari, Copacabana, Juli, Villa, Puma, Juliaca) }\end{array}$ & 17 & 3 \\
\hline $\begin{array}{l}\text { Trapiches of the natives of the Parish of Santa Barbara (ayllus } \\
\text { Paucarcolla, Taraco) }\end{array}$ & 4 & 2 \\
\hline $\begin{array}{l}\text { Trapiches of the natives of the Parish of Santiago (ayllus Guarina, } \\
\text { Tinta, Yanacona, Tuncasuca, Combapata, Langui) }\end{array}$ & 19 & 2 \\
\hline Total & $218^{67}$ & 33 \\
\hline
\end{tabular}

Source: Archivo General de Indias de Sevilla (hereafter AGI) Charcas 481 No. 19, 1763-1769.

parishes: fifty-eight trapiches (Table I) were in the hands of Spaniards and I 60 trapiches (seventy-three per cent) were in the hands of indigenous people in the ten parishes of the city. Knowing that very particular groups from different provinces arrived in a particular parish, it is very feasible that the mitayos from those communities and provinces were controlling those trapiches, or that they had some kind of arrangements with the people who owned them.

In I762, 2 I 8 trapicheros were registered, of which thirty-three (fifteen per cent) were women. Nine trapicheras were Spaniards and the rest were listed under the Indian Parishes (Figure 5), although there were also mestizas (of mixed blood).

67. I have used the same source as Tandeter for $176 \mathrm{I}-1762$, but I found only 2 I 8 trapiches instead of 235 . See Coacción y Mercado, pp. I42-143. This is because I relied on the detailed account rather than the total given by the document. 


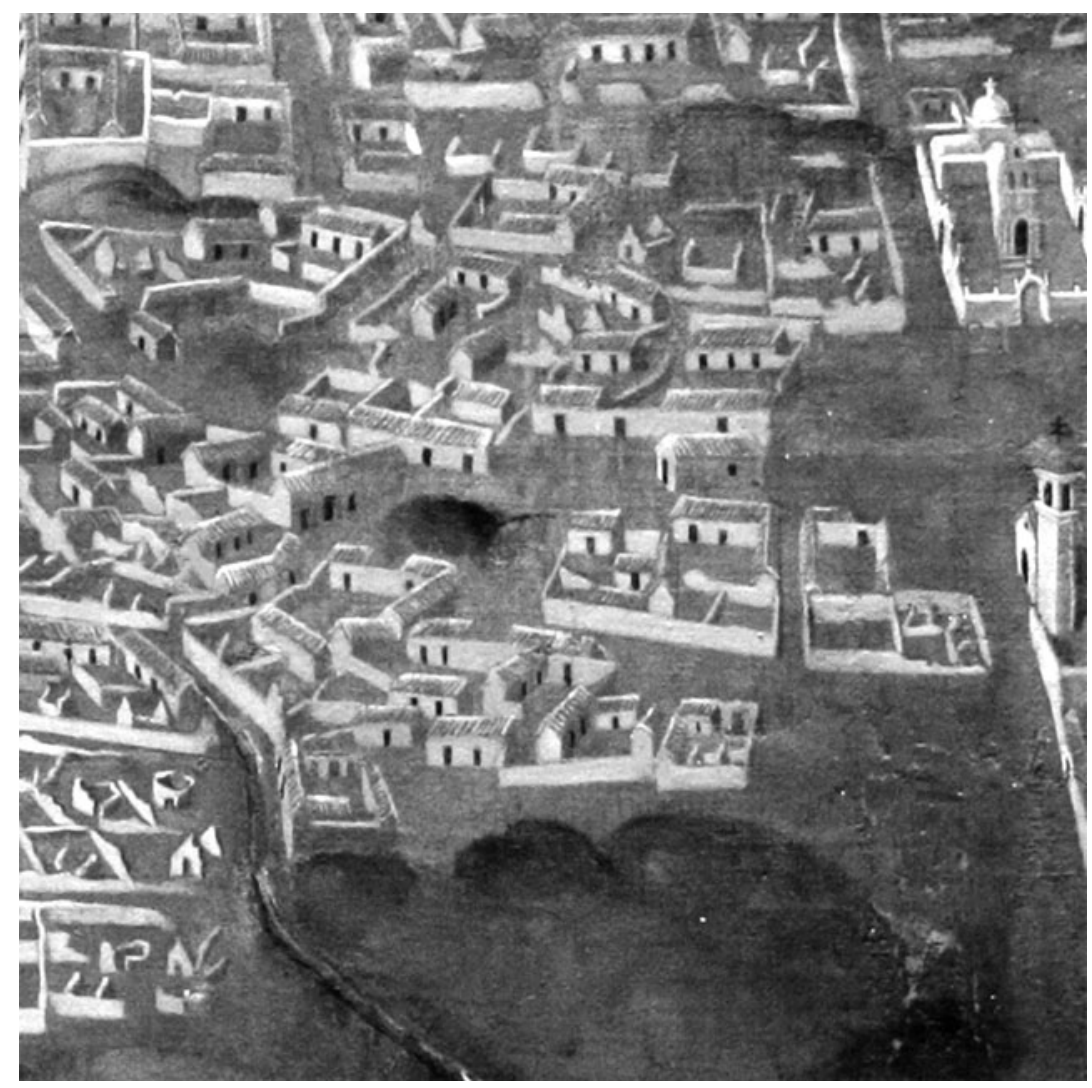

Figure 5. View from the houses of Indian parishes and neighbourhoods, according to a painting by Gaspar Miguel de Berrío, 1758. This is a fragment from the picture "Descripción del Cerro Rico e Imperial Villa de Potosí”, Museo Nacional de Charcas, Sucre.

Many names are clearly indigenous - for example, Bartholomé Canchi or María Sissa. There are others such as Juan Morales or Luisa Guevara, although Spanish patronyms do not necessarily mean that we are dealing with a non-indigenous population. In 1777, for example, Blaz de Subieta made a legal claim on behalf of his wife, Antonia Ybarra, for a trapiche that she had inherited from her late husband, Don Melchor Gutiérrez. It gradually becomes clear from the sources that the above couple were not only indigenous, but also that they were mita Indians from the ayllu Orurillo, and that Blaz de Subieta was a zambo of mixed African and indigenous ancestry. ${ }^{68}$ 
The 1762 inspection also shows that there were people who owned the trapiches and others who were renting them. In the case of Spanish women, five out of ten rented out their trapiches to other people. The prices for renting a trapiche vary considerably. Notarial records show that, in 1767 , for example, one of the most important trapicheros, the Indian Ildefonso Corimanga, rented out a trapiche with one stone to Teresa de Bonifaz for sixty pesos, ${ }^{69}$ while in 1772, Ambrocio and Cruz Martínez rented out a house-trapiche in San Pedro Parish to Antonia Montero for forty pesos a year. ${ }^{70}$

Particularly important for this study are the logbooks of daily silver sales to the Bank of San Carlos. ${ }^{71}$ In their pages, we get glimpses into the world of thousands of men and women whose names and silver deposits were registered in day-to-day operations. This information is exceptional, as it concerns people who otherwise left few traces in comparison with male wage labourers in the established mines and mills (mitayos). ${ }^{72}$

The sale of silver marks to the Bank by the trapicheros and azogueros (the reduced corporation of mine and mill owners, around thirty in the second half of the eighteenth century) in the period from 1754 to 1763 , which I have systematized, shows that women represented from ten per cent to almost twenty per cent of the total, selling between four per cent and seven per cent of the silver (Figure 6). Unfortunately, it is not possible to discern any trends because the criteria used for each year were not always the same, i.e. in 1754

69. Archivo Histórico de Potosí, Escrituras Notariales I64, f. 4I3.

70. Archivo Histórico de Potosí, Escrituras Notariales I62, f. 274.

7I. The Bank of San Carlos under total Royal control was established in 1779 , but from 1752 there was already a "Bank" (Banco de Rescates, I752-I754) to buy silver under partial royal direction. The private azogueros were involved and they had a vested interest in this institution because it provided them with loans and discounts. For the history of the Bank, see Luz María Méndez "Los bancos de rescate en Hispanoamérica (I747-I 832). El proceso histórico y sus fundamentos ideológicos. Estudio comparado para México, Perú y Chile”, D. Ávila, I. Herrera, and R. Ortiz (eds), Minería colonial Latinoamericana: Primera Reunión de Historiadores de la Minería Latinoamericana, vol. I (Mexico, I992); Guillermo Mira "El Real Banco de San Carlos y la minería altoperuano colonial, I779-1825", in J. Sánchez, G. Mira, and R. Dobado (eds), La savia del Imperio (Salamanca, 1997). See its constitution in: AGI Buenos Aires 440. Real Cédula de Incorporación del Banco de Potosí a la Real Hacienda y ordenanzas para su régimen y gobierno (Madrid, 1795 ).

72. There were daily transactions: from sixteen to twenty every day, ranging from 500 transactions for some months, to just two transactions on some days. The earlier logbooks of the Bank at the Potosí Archive mention only the azogueros and trapicheros, while the title of the 1788 logbook is "Libro de compras de pinas de trapicheros y ccachas", AHP, Banco de San Carlos (hereafter, BSC) 383 . This diverse documentation indicates a sharp distinction between azogueros and $k$ 'ajchas and trapicheros (who are identified with one another). "Libro donde se sientan los marcos que se traen al rescate de los trapicheros de esta rivera”, I76 I-1764, AHP, BSC $3 \mathrm{I}_{3}$ (for trapicheros); “Libro donde se asientan los marcos de plata que los señores azogueros de esta villa traen a rescatar a este banco y mercadería que corre a cargo del maestre de campo", I759-1762, AHP, BSC 360 (for azogueros). Sometimes, the logbooks include trapicheros and azogueros simultaneously, i.e. in 1754,1755 , and 1757 . 


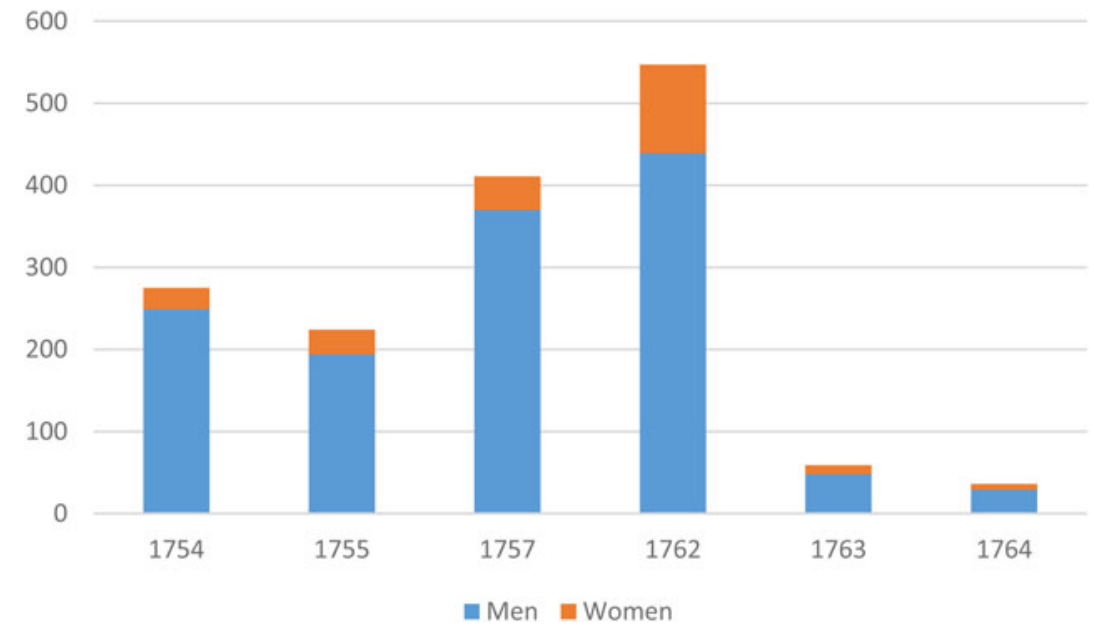

Figure 6. Numbers of men and women selling their silver to the Bank, $1754^{-1762 .}$ Source: same as Table 2.

and 1755 , not all the months were registered and, in 1757 , the data include the silver from outside the city of Potosí (see Table 2).

It is important to mention that the trapicheros were a group with significant internal differences. In I 762, a large proportion of women (around seventy per cent) carried out just a single transaction. At the other extreme, a few women were selling thirty-nine per cent in 1762 (see Table 3 ).

It is worth mentioning a few particular cases for the same year. Christina Cupi, identified as an indigenous woman, sold ore from January to March in fifteen transactions of between eleven and fifty-eight pesos for 473 pesos' worth in total. That amount is impressive if we consider that the annual tribute due from Indian males was around nine to ten pesos per year, that the wage of a mitayo was twelve pesos per month (three pesos a week), and that the wage of a minga was twenty-eight pesos per month (seven pesos a week). If Christina had to work all year long as a minga, she could have earned just 336 pesos. She obtained, then, in three months, more than an annual wage. Another woman, Thomasa Mercado, engaged in the same number of transactions but she sold what she had for 228 pesos, half the amount of Christina Cupi. María Rosel and María Gimenez conducted, in contrast, several transactions throughout the year, selling for more than 2,000 pesos each. Among the men, Francisco Chamoso and Diego Iporre were the most important sellers. The former, who appears in other documents described as a Spaniard, obtained I 8,856 pesos from fifty-five transactions, while the latter sold 22,249 pesos' worth of ore in fifty-seven transactions.

This analysis of $k$ 'ajchas and trapiches allows us to approach them in a different way. They became self-employed workers who challenged the 
Table 2. Number of women, their transactions and total silver sold to the Bank, I754-I763.

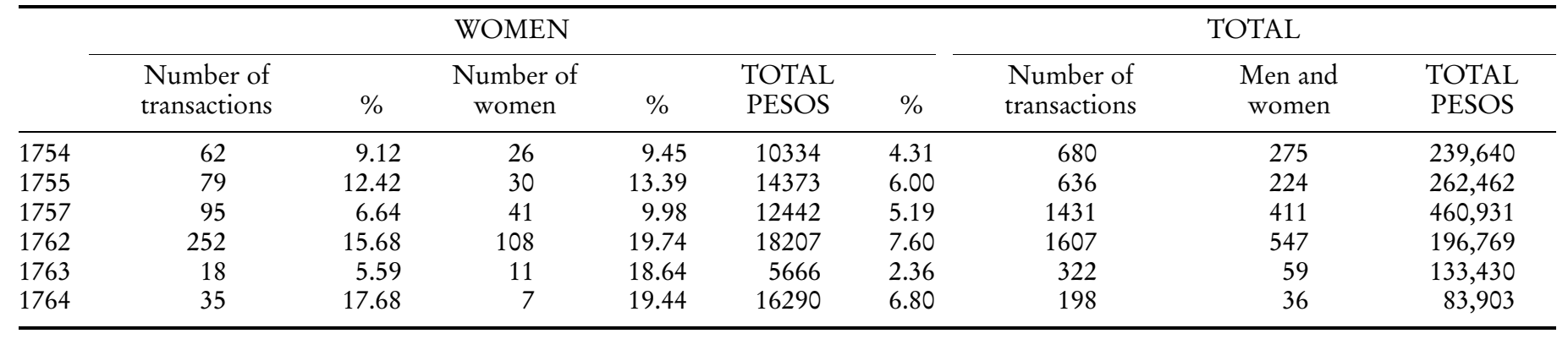

Sources: Archivo Potosí-Casa Nacional de la Moneda, Banco de San Carlos. For just trapicheros from 1762 to 1764 see BSC 313, Libro donde se sientan los marcos que se traen al rescate de los trapicheros de esta rivera, 1761-1764; for 1754, 1755, and 1757 both azogueros and trapicheros are included: BSC 325 Libro de los azogueros desta Rivera, Trapicheros de esta villa y otras personas. 
Table 3. Number of women's transactions from the trapicheras and amount of ore sold in 1762 (in pesos).

\begin{tabular}{lcrcc}
\hline & \multicolumn{4}{c}{$\mathbf{1 7 6 2}$} \\
\cline { 2 - 5 } Number of transactions & Number of people & $\%$ & Pesos & $\%$ \\
\hline 1 transaction & 72 & $\mathbf{6 9 . 9 0}$ & 5,419 & $\mathbf{2 9 . 7 8}$ \\
2 to 5 & 21 & 20.39 & 5,514 & $\mathbf{3 0 . 3 0}$ \\
6 to 10 & 4 & 3.88 & 3,127 & 17.18 \\
11 to 20 & 6 & 5.83 & 4,139 & 22.74 \\
21 to 50 & & & & \\
More than 50 & 103 & & 18,199 & 100.00 \\
Total & & & & \\
\hline
\end{tabular}

Source: Archivo Potosí-Casa Nacional de la Moneda, Banco de San Carlos. BSC 313, Libro donde se sientan los marcos que se traen al rescate de los trapicheros de esta rivera, $1761-1764$.

ownership of the proprietors of the mines in the Potosí mountain. Through their own labour and initiative, they effectively asserted their right to take a significant share of the revenue from ore extraction.

\section{CONCLUSIONS}

Conditions of precariousness in the sense of bad working conditions and insecurity were the norm in the world of mining and, after I 575 , some spheres were more precarious than others. It is important to remember that, at the beginning of the exploitation of the mountain of Potosí, different groups had greater access to the ore and the role of indigenous people in the smelting process was crucial. Indigenous women were also actively involved as traders of ore in the local market. Between 1570 and I 575 , the technological changes and the reorganization of labour established by the Spanish Crown transformed the previous situation. The main division in the mines was established between the owners of refineries, who worked with sophisticated mills and received important contingents of workers through the mita system or unfree work. The main conditions of production were then facilitated for a group of private entrepreneurs. Studies on the mines have foregrounded the formal and privileged sphere of mining and refining, and the male sphere of workers. Mining appears to have been much more male. However, their families became involved as what is now called the "unpaid contributing family worker", a group whose participation in the mining economy deserves to be highlighted. In this paper, I underlined the importance of considering that silver was obtained through a long process that required work underground and above ground, as Dana Velasco Murillo has suggested for Mexico. The former was a male sphere, but, in the latter case, women and the young participated, as 
part of a gender and age division of labour that still exists in countries like Bolivia. Moreover, the demand for silver drove the development of other activities outside the privileged mining enterprises that used to receive workers from a wide area.

More traditional and rudimentary technology also existed throughout the colonial period in the hands of self-employed people, some of whom were women. This "informal" world was much broader and diverse but crucial to the subsistence and life of families and households. Sources are undoubtedly scarce outside the privileged sphere of the entrepreneurs. The book of daily sales of ore to the Bank is a unique document that offers a completely different picture of mining and women in mining. It is clear that they were already in a very disadvantaged position in comparison with the owners of the refineries and, in order to be able to produce by themselves and without any support, they had to "exploit" their labour in precarious conditions.

This article has been an attempt to make women in mining visible, and clearly their history, delineated here, is just the tip of the iceberg. Without a careful reading of documents, women will remain as invisible as the sources about them, and the gender bias of such sources are sustained. 